\title{
Deltamethrin induced alterations of hematological and biochemical parameters in fingerlings of Catla catla (Ham.) and their amelioration by dietary supplement of vitamin C
}

\author{
T. Vani ${ }^{\text {a }}$, N. Saharan ${ }^{\text {a }}$, S.C. Mukherjee ${ }^{\text {b }}$, Ritesh Ranjan ${ }^{\text {b,1 }}$, Rajesh Kumar ${ }^{\text {b, } * 2,}$, R.K. Brahmchari ${ }^{\text {b,3 }}$ \\ a Inland Aquaculture Division, Central Institute of Fisheries Education (CIFE), Mumbai 400 061, India \\ ${ }^{\mathrm{b}}$ Aquatic Animal Health Management Division, CIFE, Mumbai 400 061, India
}

\section{A R T I C L E I N F O}

\section{Article history:}

Received 12 January 2011

Accepted 28 May 2011

Available online 7 June 2011

\section{Keywords:}

Pyrethroid

Vitamin C

Toxicity

Hematology

Enzyme activities

Catla catla

\begin{abstract}
A B S T R A C T
The present study was carried out to investigate the sub-lethal toxicity of technical grade deltamethrin (a synthetic pyrethroid) of concentration $1.61 \mu \mathrm{g} / \mathrm{L}\left(1 / 3 \mathrm{rd}\right.$ of $\left.96 \mathrm{~h} \mathrm{LC} \mathrm{C}_{50}\right)$ on hematological and biochemical parameters of catla (Catla catla) fingerlings and its amelioration through dietary vitamin C. The deltamethrin exposed fishes were fed with different levels of supplemented vitamin $C$ such as 50, 250, 500 and $1000 \mathrm{mg} / \mathrm{kg}$ diet to see its ameliorating effect by assaying hematological parameters viz. total erythrocyte count (TEC), total leukocyte count (TLC), hemoglobin content ( $\mathrm{Hb}$ ), total serum protein, albumin, globulin, albumin-globulin ratio and biochemical parameters such as lactate dehydrogenase (LDH), acetylcholine esterase (AChE), alanine amino transferase (ALT), aspartate amino transferase (AST), total adenosine triphosphatase (ATPase), magnesium adenosine triphosphatase $\left(\mathrm{Mg}^{2+}\right.$-ATPase) and sodium potassium adenosine triphosphatase $\left(\mathrm{Na}^{+}, \mathrm{K}^{+}\right.$-ATPase) activities. The finding of this study showed that deltamethrin had negative effect on the hematological and biochemical parameters of Catla catla. The experimental group, which was exposed to deltamethrin and fed with normal diet showed significantly lower values $(P \leqslant 0.05)$ of all parameters studied except ALT activity. This might be due to possible disruption of hematopoiesis and proteosynthesis. However, the fish fed with varied concentration of vitamin $C$ in diets neutralized the toxic effect of deltamethrin, as evidenced by significantly lowered hematological and biochemical response. Vitamin C @ $1000 \mathrm{mg} / \mathrm{kg}$ diet was the most effective in amelioration of harmful effect of deltamethrin on hematological and biochemical parameters of catla fingerlings. The result suggests that vitamin $C$ can be effectively used to neutralize the toxic effect of deltamethrin on catla.
\end{abstract}

(c) 2011 Elsevier Inc. All rights reserved.

\section{Introduction}

The synthetic pyrethroids is a diverse class of more than 1000 powerful broad spectrum insecticides that are environmentally compatible by virtue of their moderate persistence, low volatility and poor aqueous mobility in soil [1]. Due to their high efficacy, easy biodegradability and low toxicity in birds and mammal [2], synthetic pyrethroids are chosen over organochlorine, organophosphorus and carbamate insecticides [3].

\footnotetext{
* Corresponding author. Address: Central Institute of Freshwater Aquaculture (CIFA), Kausalyaganga, Bhubaneswar 751 002, Orissa, India. Fax: +916742465407. E-mail address: rajeshfishco@yahoo.co.uk (R. Kumar).

1 Mariculture Division, VRC of CMFRI, Visakhapatnam 530 003, Andhra Pradesh, India.

2 Aquaculture Production \& Environment Division, CIFA, Bhubaneswar 751002 Orissa, India.

${ }^{3}$ Microbiolgy Division, College of Fisheries, Dholi, Pusa, Samastipur 848 125, Bihar, India.
}

Deltamethrin, a synthetic pyrethroid is used to control the pests of various agricultural crops, used in public health programme and protection of stored crops [4]. The extensive use of deltamethrin on land may be washed into surface water and kill or at least adversely influence the life of aquatic organisms and other higher animals. Aquatic organisms, particularly fish, are highly sensitive to deltamethrin [5-7]. The toxicity may be lethal to fish or may lead to stress which in turn causes immunosuppression and susceptibility to secondary infection.

The effects of insecticide pollution on non-target organisms in the environment can be studied by detecting changes in organisms at the physiological, biochemical or molecular levels, providing "early warning" tools in monitoring environment quality $[8,9]$. These sensitive early warning biomarkers can measure interaction between environmental xenobiotics and biological effects. Inhibition and induction of these biomarkers is a good approach to measure potential impacts of pollutants on environmental organisms [10]. The analysis of hematological and biochemical parameters 
in fish can contribute to the assessment of the animal's health and also the habitat conditions [11].

Most fish species cannot synthesize vitamin C, and have to depend on external sources to meet their needs [12]. The vitamin C requirement for normal growth and survival is quite low [13], however, a higher level is required to improve the stress resistance of fish [14]. The dietary supplementation of ascorbic acid at higher doses could counter the stress of the pesticide deltamethrin in Clarias gariepinus [15]. Similar results were also reported by other authors [16,17].

Several studies have been carried out on the effect of different pesticides on hematological and biochemical aspects of fish and other aquatic animals, but very few on its amelioration through dietary vitamin C. Especially, there is lack of data on this topic in relation to Catla catla species. Considering the commercial value of this species, it is necessary to obtain scientific information about the effect of deltamethrin on Catla catla to improve risk-assessment studies and its attenuation with the help of dietary Vitamin C. The main objective of this study was to assess the effect of single sub-lethal concentration of deltamethrin over a long exposure period on hematological and biochemical parameters of Catla catla and its amelioration through a gradient of dietary Vitamin C.

\section{Materials and methods}

\subsection{Fish and husbandry}

Fingerlings of catla weighing $14 \pm 0.2 \mathrm{~g}$ were brought from a commercial fish farm at Palghar, Mumbai, India and were used in the experimental study. Fishes were acclimatized for 2 weeks prior to experimentation. Chlorine free tap water was used throughout the course of the experiment. The physico-chemical characteristics of the test water were as follows: temperature $27 \pm 2.0^{\circ} \mathrm{C}$; $\mathrm{pH} 7.4$; hardness $80 \mathrm{mg} \mathrm{l}^{-1}$ (as $\mathrm{CaCO}_{3}$ ); alkalinity $88 \mathrm{mg} \mathrm{l}^{-1}$ (as $\mathrm{CaCO}_{3}$ ) and dissolved oxygen concentration $5.6 \pm 0.2 \mathrm{mg} \mathrm{l}^{-1}$.

\section{2. $L C_{50}$ of deltamethrin}

Technical grade deltamethrin [S (a) cyano-3-phenoxybenzyl (1R, 3R)-3-(2, 2-dibromovinyl)-2, 2-dimethylcyclopropane-carboxylate [from Tagrose Chemical India Ltd., Chennai, India] with active ingredient $98 \%$ was used for the experiment. The $\mathrm{LC}_{50}$ value of deltamethrin was determined in the laboratory starting with range finding test to acute toxicity trials [18]. Two hundred and sixteen fishes were randomly distributed in eighteen rectangular plastic tanks $(100 \mathrm{~L})$ filled with different concentrations of deltamethrin solution $\left(2,4,6,8\right.$ and $\left.10 \mu \mathrm{g} \mathrm{l}^{-1}\right)$ and a control group, water without deltamethrin, in triplicate. The mortality was recorded for $96 \mathrm{~h}$ at regular intervals of $12 \mathrm{~h}$ and dead fish were counted and immediately removed. The LC50 value of deltamethrin was calculated with the help of probit analysis using SPSS version 12. One-third concentration $\left(1.61 \mu \mathrm{g} \mathrm{l}^{-1}\right)$ of calculated $\mathrm{LC}_{50}$ was selected for sub lethal test trails.

\subsection{Experimental diets}

In our study, four different vitamin $C$ levels were used for formulation of experimental diets. L-ascorbyl 2-polyphosphate (Sisco Research Laboratories pvt. Ltd., Mumbai, India) was used as the vitamin C source. A basal diet composed of $30 \%$ soybean meal, $18 \%$ wheat flour, $13 \%$ rice polish, $13 \%$ fish meal, $10 \%$ corn flour, $10 \%$ sunflower oilcake, $4 \%$ sunflower oil, $1 \%$ mineral and vitamin mixture (each $100 \mathrm{~g}$ mineral and vitamin mixture contain Vitamin A 200,000 IU; Cholecalciferol 40,000 IU; Vitamin B2 80 mg; Vitamin E 30 units; Vitamin K 40 mg; Calcium pantothenate 100 mg;
Nicotinamide $400 \mathrm{mg}$; Vitamin B12 $240 \mathrm{mg}$; Choline chloride $6 \mathrm{~g}$; Calcium $30 \mathrm{~g}$; Manganese $1.1 \mathrm{~g}$; Iodine $40 \mathrm{mg}$; Iron $300 \mathrm{mg}$; zinc $600 \mathrm{mg}$; copper $80 \mathrm{mg}$; cobalt $18 \mathrm{mg}$ ) and $1 \% \mathrm{CMC}$ as binder was used. The experimental diets were prepared by incorporating vita$\mathrm{min} C$ in the basal diet at the rate of $50,250,500$ and $1000 \mathrm{mg} / \mathrm{kg}$ of feed. All the feed ingredients were mixed thoroughly, and dough was prepared with required amount of water. Then dough was conditioned for $1 \mathrm{~h}$ followed by steaming for $20 \mathrm{~min}$. After cooling, minerals and vitamins mixture and vitamin $C$ were added to the dough and mixed thoroughly. The dough was pressed through a hand pelletizer $(0.2 \mathrm{~mm})$. Pellets were dried and stored at $4{ }^{\circ} \mathrm{C}$.

\subsection{Experimental design}

Fifteen rectangular plastic tanks (100 L) were arranged with continuous aeration. One hundred and eighty fingerlings $(14 \pm 0.2 \mathrm{~g})$ were randomly distributed equally in five treatment groups with each of three replicates following a complete randomized design. All treatment groups (B, C, D and E) were exposed to sub lethal concentration of $\mathrm{LC}_{50}$ of deltamethrin $\left(1.61 \mu \mathrm{g} \mathrm{l}^{-1}\right)$ except group A. In the diets of treatment groups A and B, a normal required dose of vitamin C (50 mg/kg feed) was incorporated while in the diets of treatment groups $\mathrm{C}, \mathrm{D}$ and $\mathrm{E}$ a different high doses of vitamin C @ 250, 500, and $1000 \mathrm{mg} / \mathrm{kg}$ feed were incorporated respectively. The feed was fed twice daily $(0700$ and $1700 \mathrm{~h})$ to the approximate satiation for 45 days. Every day morning, the test solution (water containing $1.61 \mu \mathrm{g} \mathrm{l}^{-1}$ deltamethrin concentration) of groups B, C, D and E, was completely renewed with fresh one to maintain the required deltamethrin concentration of $1.61 \mu \mathrm{g}^{-1}$. Group A water was also completely changed every day with normal water.

\subsection{Hematological studies}

Blood was drawn from the caudal peduncle region using a sterile $2 \mathrm{ml}$ syringe rinsed with $2.7 \%$ EDTA solution. Blood was then collected in small glass vials coated with $20 \mu$ of $2.7 \%$ EDTA solution.

Total erythrocytes count (TEC) and total leukocytes counts (TLC) were estimated using the method of Schaperclaus et al. [19]. The cells were counted using a hemocytometer (Feinoptik, Blakenburg, Germany) and expressed as:

Number of $\mathrm{RBC} / \mathrm{mm}^{3}=\mathrm{Nr} \times 10,000$

Number of $\mathrm{WBC} / \mathrm{mm}^{3}=\mathrm{Nw} \times 500$

where $N_{r}$ is the total number of red blood cells counted in five squares of the hemocytometer and 10,000 is the factor obtained after taking into consideration the initial dilution factor and $N_{w}$ denotes the total number of white blood cells counted in four squares of the hemocytometer and the factor obtained after taking into consideration the initial dilution factors was 500 . The blood hemoglobin content $(\mathrm{Hb})$ was analyzed following the Cyanmethemoglobin method using Darbkins fluid (Qualigens diagnostics kit, Mumbai, India).

\subsection{Serum parameters}

Blood was collected from caudal region of fish without rinsing the syringe with anticoagulants and collected in clean and dry Eppendorf tube. The blood was allowed to clot for $45 \mathrm{~min}$ in inclined position at room temperature followed by $30 \mathrm{~min}$ incubation at $4{ }^{\circ} \mathrm{C}$ and then centrifuged at $3000 \mathrm{~g}$ for $10 \mathrm{~min}$ at $4{ }^{\circ} \mathrm{C}$. 
Serum was collected in sterilized eppendorf tube and analyzed for the different serum parameters in AR 601, semi automatic analyzer (Qualigens, India) using Qualigens diagnostic kits. The serum parameters studied were total serum protein (biuret method using buffered dye reagent and biuret reagent) and albumin (bromocresol green binding method). The globulin level was estimated by subtracting albumin content from total serum protein content and the albumin-globulin ratio was obtained by dividing albumin content by globulin content.

\subsection{Enzyme assay}

At the end of experiment (45th day), fishes were sacrificed for the collection of brain, liver and gill to carry out the enzyme assay. Five fish from each replicate of a treatment were sacrificed for tissue collection. Tissue was homogenized in chilled sucrose solution $(0.25 \mathrm{M})$ in Teflon coated mechanical tissue homogenizer (Remi, India) and centrifuged at $5000 \mathrm{~g}$ at $4{ }^{\circ} \mathrm{C}$ for $10 \mathrm{~min}$. The supernatant was used as an enzyme source for measuring enzymatic activity. All the enzyme preparation was carried out in chilled condition. Dilution of the sample was done as and when required.

Lactate dehydrogenase (LDH, E.C.1.1.1.27) activity in the liver was measured by the change in optical density (OD) at $340 \mathrm{~nm}$ for 5 min using the method of Wrobleuiski and Ladue [20]. Aspartate amino transferase (AST, E.C.2.6.1.1) and alanine amino transferase (ALT, E.C.2.6.1.2) activities in liver were measured by the estimation of oxaloacetate and pyruvate released, respectively, after incubation of the reaction mixture at $37^{\circ} \mathrm{C}$ for $60 \mathrm{~min}$ [21]. Acetylcholine esterase (AChE, E.C.3.1.1.7) activity in brain was measured by the change in optical density (OD) at $540 \mathrm{~nm}$ by following the method of Hestrin [22] modified by Augustinsson [23].

Total adenosine triphosphatase (ATPase) activity (E.C.3.6.1.3) in gill was assayed in a reaction mixture of $0.1 \mathrm{M}$ Tris- $\mathrm{HCl}$ buffer $(\mathrm{pH}$ 7.8), $100 \mathrm{mM} \mathrm{NaCl}, 20 \mathrm{mM} \mathrm{KCl}, 3 \mathrm{mM} \mathrm{MgCl}$ and $5 \mathrm{mM}$ ATP. The mixture was incubated for $15 \mathrm{~min}$ and the reaction was terminated by means of $10 \%$ trichloroacetic acid [24]. Phosphate liberated was estimated at $660 \mathrm{~nm}$ [25]. A similar reaction mixture was used for the estimation of magnesium adenosine triphosphatase $\left(\mathrm{Mg}^{2+}-\right.$ ATPase) activity (E.C.3.6.3.1) in gill except $0.1 \mathrm{ml}$ of $1 \mathrm{mM}$ of ouabain used for termination of reaction. Sodium potassium adenosine triphosphatase $\left(\mathrm{Na}^{+}, \mathrm{K}^{+}\right.$-ATPase $)$activity in gill was estimated by subtracting $\mathrm{Mg}^{2+}$-ATPase activity from total ATPase activity. All the colorimetric assays were carried out using UV-VIS spectrophotometer (E-Merck, Germany).

\subsection{Statistical analysis}

The data of 45 days sub-lethal toxicity test was statistically analyzed by using SPSS version 12.0 subjected to one-way ANOVA analysis. Duncan's multiple range tests was carried out for post hoc comparison of mean. A significance level of $P \leqslant 0.05$ was used.

\section{Results}

In the present study, the $96 \mathrm{~h} \mathrm{LC}_{50}$ of deltamethrin was found to be $4.84 \mu \mathrm{g} \mathrm{l}^{-1}$. The effect of vitamin $C$ supplemented diet on hematological parameters and serum biochemistry of different experimental groups are shown in Table 1 . The TEC, TLC, hemoglobin content, total serum protein, serum globulin, serum albumin, serum albumin: globulin ratio were significantly lower $(P \leqslant 0.05)$ in group B in comparison to other groups. The group A showed similarity with group $\mathrm{E}$ in respect to hematological parameters.

Data on the effect of vitamin C supplemented diet on the enzymatic activities of various metabolic pathways are summarized in Table 2. The AChE activity in brain and LDH activity in liver were significantly lower $(P \leqslant 0.05)$ in group B in comparison to group A where as group $E$ showed similarity with group A. The enzyme activity of energy metabolism (total adenosine triphosphatase, sodium potassium adenosine triphosphatase and magnesium adenosine triphosphatase) in gill were significantly lower $(P \leqslant 0.05)$ in group B fishes in comparison to group A while in group $E$, it was similar to group A. The protein metabolic enzyme, ALT activity in liver increased significantly $(P \leqslant 0.05)$ in group $B$ fish in comparison to group A while AST activity in liver was significantly lower $(P \leqslant 0.05)$ in group B. But both AST and ALT activity in group E fishes were similar to group $A$.

\section{Discussion}

The study result indicated a significant decrease in TEC and $\mathrm{Hb}$ after exposure to a sub-lethal dose of deltamethrin pesticide establishes a condition of erythropenia and hemolysis in Catla catla. The reduction in TEC and $\mathrm{Hb}$ might be due to the inhibition of erythropoiesis, hemosynthesis, osmoregulatory dysfunction or due to increased rate of erythrocyte destruction in the hematopoietic organ, as reported in Cyprinus carpio exposed to endosulfan [26]. Svobodova et al. [27] also reported significantly lower values of red blood cells and $\mathrm{Hb}$ in Cyprinus carpio after acute exposure to deltamethrin. The TLC was significantly less $(P \leqslant 0.05)$ in group $B$ fishes which was exposed to deltamethrin but fed normal diet. The similar finding was reported in the blood of Ctenopharyngodon idella exposed to fenvalerate [28] and in carp following acute poisoning with permethrin [29]. However, group E fed with high level of vitamin C shows similar TEC, TLC and $\mathrm{Hb}$ in comparison to the control group A. This indicates that vitamin C @ $1000 \mathrm{mg} / \mathrm{kg}$ diet of fish minimized the toxic effect of deltamethrin and stimulated immune response to cope up the deltamethrin stress. Vitamin C is proved to increase phagocytic activity, natural complement and respiratory burst activity in gilthead sea bream Sparus aurata, for a short period after which it returns to its normal level [30]. They also suggested that vitamin $C$ is highly interactive and may fortify anti-oxidant defense and enhance immune response directly by maintaining optimal vitamin $E$ level. Vitamin $C$ is an effective ameliorating agent against stress and can enhance nonspecific immune response in Atlantic salmon exposed to $2 \mathrm{~h}$ confinement stress [31]. Agrawal [32] reported that the massive dose of $500 \mathrm{mg}$ ascorbic acid per $100 \mathrm{~g}$ of aldrin mixed diet significantly lowered the hematological response to aldrin pollution such as in erythrocyte number and hemoglobin percentage. The findings of our study suggests that high dose of vitamin $C$ might be helpful in reducing the harmful effect of deltamethrin on TEC, $\mathrm{Hb}$ and TLC by maintaining optimum level of vitamin $\mathrm{E}$.

The significant decrease $(P \leqslant 0.05)$ in total serum protein was found in fishes exposed to deltamethrin and fed with normal diet (group B). This might be due to breakdown of total protein for energy purpose. Similar result was observed in common carp exposed to deltamethrin [27], bifenthrin [33] and in Korean rock-fish (Sebastes schlegeli) on exposure to cypermethrin [34]. Hussein et al. [35] opined that the decrease in total protein was mainly due to increased effects on immune system of the fish. The increase in total serum protein in groups fed with vitamin $C$ supplemented diet indicates a reduction in enzymatic breakdown of serum protein for energy purpose. The improved level of total serum protein in group $\mathrm{E}$ might be due to reduction of stress by heavy dose of vitamin $C$. In the present study, significantly low $(P \leqslant 0.05)$ globulin content were observed in group $B$, which was fed with normal diet and exposed to deltamethrin. Globulin content of group E (vitamin C @ $1000 \mathrm{mg} / \mathrm{kg}$ diet) was significantly similar to group A. This result shows that vitamin C @ $500 \mathrm{mg} / \mathrm{kg}$ diet was able to improve the immune system of fish under the stress of pesticide. 
Table 1

Effect of vitamin C supplemented feed on the hematology and serum biochemistry of Catla catla exposed to sub-lethal deltamethrin concentration for 45 days.

\begin{tabular}{|c|c|c|c|c|c|c|c|}
\hline Treatments & $\begin{array}{l}\text { Total erythrocytes } \\
\text { count }\end{array}$ & $\begin{array}{l}\text { Total leukocytes } \\
\text { count }\end{array}$ & $\begin{array}{l}\text { Hemoglobin } \\
\text { content }\end{array}$ & $\begin{array}{l}\text { Total serum } \\
\text { protein }\end{array}$ & $\begin{array}{l}\text { Albumin } \\
\text { content }\end{array}$ & $\begin{array}{l}\text { Globulin } \\
\text { content }\end{array}$ & $\begin{array}{l}\text { Albumin-globulin } \\
\text { ratio }\end{array}$ \\
\hline A & $1.39^{\mathrm{a}} \pm 0.07$ & $4.11^{\mathrm{a}} \pm 0.19$ & $9.17^{\mathrm{a}} \pm 0.57$ & $4.39^{\mathrm{a}} \pm 0.11$ & $1.87^{\mathrm{a}} \pm 0.06$ & $2.52^{\mathrm{a}} \pm 0.05$ & $0.74^{\mathrm{a}} \pm 0.00$ \\
\hline B & $0.96^{c} \pm 0.03$ & $2.85^{\mathrm{d}} \pm 0.16$ & $4.00^{C} \pm 0.29$ & $2.71^{\mathrm{d}} \pm 0 . .06$ & $0.96^{\mathrm{d}} \pm 0.03$ & $1.75^{c} \pm 0.03$ & $0.54^{c} \pm 0.01$ \\
\hline $\mathrm{C}$ & $1.20^{\mathrm{b}} \pm 0.05$ & $3.18^{\mathrm{cd}} \pm 0.13$ & $6.33^{\mathrm{b}} \pm 0.40$ & $3.38^{\mathrm{c}} \pm 0.10$ & $1.28^{\mathrm{c}} \pm 0.05$ & $2.10^{\mathrm{b}} \pm 0.06$ & $0.60^{\mathrm{b}} \pm 0.00$ \\
\hline $\mathrm{D}$ & $1.26^{\mathrm{ab}} \pm 0.04$ & $3.36^{\mathrm{bc}} \pm 0.01$ & $7.22^{\mathrm{b}} \pm 0.67$ & $3.94^{\mathrm{b}} \pm 0.08$ & $1.54^{\mathrm{b}} \pm 0.05$ & $2.40^{\mathrm{a}} \pm 0.03$ & $0.64^{\mathrm{b}} \pm 0.01$ \\
\hline $\mathrm{E}$ & $1.33^{\mathrm{ab}} \pm 0.05$ & $3.75^{\mathrm{ab}} \pm 0.14$ & $7.94^{\mathrm{ab}} \pm 0.58$ & $4.15^{\mathrm{ab}} \pm 0.09$ & $1.75^{a} \pm 0.06$ & $2.40^{\mathrm{a}} \pm 0.03$ & $0.73^{a} \pm 0.02$ \\
\hline
\end{tabular}

Different superscripts in column for individual indicate significant difference $(P \leqslant 0.05)$.

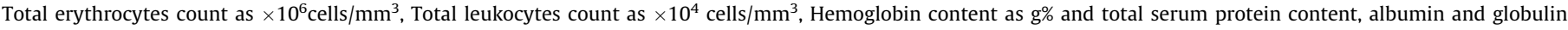
content as g/dl.

Table 2

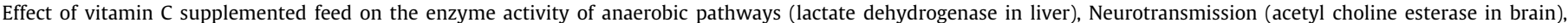

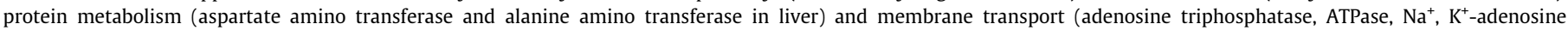
triphosphatase and $\mathrm{Mg}^{2+}$-adenosine triphosphatase in gill) of Catla catla exposed to sub-lethal deltamethrin concentration for 45 days.

\begin{tabular}{|c|c|c|c|c|c|c|c|}
\hline Treatments & LDH activity & AChE activity & ALT activity & AST activity & Total ATPase activity & $\mathrm{Na}^{+}, \mathrm{K}^{+}$-ATPase activity & $\mathrm{Mg}^{2+}$-ATPase activity \\
\hline A & $0.31^{a} \pm 0.02$ & $0.56^{\mathrm{a}} \pm 0.03$ & $7.60^{c} \pm 0.58$ & $2.64^{a} \pm 0.20$ & $66.85^{a} \pm 5.10$ & $20.69^{a} \pm 1.73$ & $46.16^{a} \pm 3.38$ \\
\hline B & $0.21^{\mathrm{c}} \pm 0.01$ & $0.39^{c} \pm 0.01$ & $11.24^{\mathrm{a}} \pm 0.72$ & $1.45^{\mathrm{d}} \pm 0.14$ & $28.29^{c} \pm 2.47$ & $9.61^{d} \pm 0.57$ & $18.68^{\mathrm{c}} \pm 1.83$ \\
\hline C & $0.25^{\mathrm{bc}} \pm 0.01$ & $0.41^{\mathrm{c}} \pm 0.01$ & $9.71^{\mathrm{ab}} \pm 0.41$ & $1.61^{\mathrm{cd}} \pm 0.12$ & $38.07^{\mathrm{c}} \pm 2.92$ & $11.89^{\mathrm{cd}} \pm 1.15$ & $26.18^{\mathrm{c}} \pm 1.77$ \\
\hline D & $0.27^{\mathrm{ab}} \pm 0.01$ & $0.47^{b c} \pm 0.02$ & $8.77^{b c} \pm 0.45$ & $2.01^{\mathrm{bc}} \pm 0.19$ & $52.16^{\mathrm{b}} \pm 4.13$ & $15.69^{\mathrm{bc}} \pm 1.55$ & $36.47^{b} \pm 2.58$ \\
\hline $\mathrm{E}$ & $0.28^{\mathrm{ab}} \pm 0.02$ & $0.52^{\mathrm{ab}} \pm 0.03$ & $8.18^{b c} \pm 0.29$ & $2.27^{\mathrm{ab}} \pm 0.15$ & $62.23^{\mathrm{ab}} \pm 2.88$ & $17.10^{\mathrm{ab}} \pm 0.87$ & $45.13^{a} \pm 2.02$ \\
\hline
\end{tabular}

Different superscripts in column for individual parameter indicate significant difference $(P \leqslant 0.05)$.

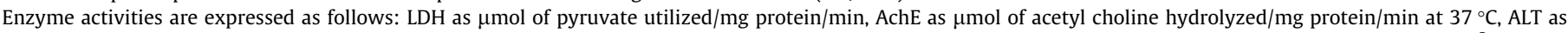

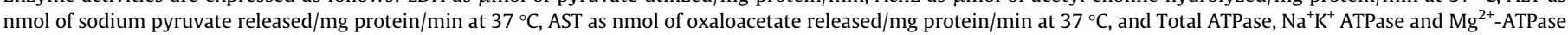
as $\mu \mathrm{g}$ of phosphorus/mg protein $/ \mathrm{min}$ at $37^{\circ} \mathrm{C}$.

But vitamin C@ more than that of $500 \mathrm{mg} / \mathrm{kg}$ diet can help the fish to completely come out of pesticide stress and stimulate their immune system towards good health condition.

The albumin has been reported to be an osmoregulator of blood volume, an easily available protein reserve and a transport protein [36]. Dutta [37] described that hyperactivity caused by deltamethrin may lead to the utilization of this easily accessible protein reserve-fraction containing albumin, resulting in a decreased quantity. Another possible reason for the lowered amount of albumin may be a decreased albumin synthesis in the hepatocytes [38]. In the present study, similar findings have been noticed when exposed with deltamethrin and fed with normal diet (group B). Improvement in albumin content was observed with the increased supplementation of vitamin C in group C, D and E (vitamin C @ 250,500, $1000 \mathrm{mg} / \mathrm{kg}$ diet respectively) compared to group B. This indicates that vitamin $C$ reduces stress depending upon dose administered in fish and thereby minimizes the breakdown of albumin. The minimum albumin-globulin ratio in group B was mainly due to heavy breakdown of albumin under deltamethrin stress. Albumin-globulin ration was better in group $\mathrm{E}$, this indicates that the albumin and globulin breakdown were at minimum because of less stress due to vitamin C. Nayak et al. [39] reported a similar result upon permethrin (a pyrethroid insecticide) exposure to Labeo rohita.

Toxicants have been shown to cause alterations in the activities of many enzymes concerning to cellular energy metabolism $[40,41]$. In the present study, the activity of the liver LDH (the terminal enzyme of glycolytic pathway) showed maximum inhibition in the group fed with normal diet and exposed to deltamethrin (Group $B$ ). However, in the group fed diet containing high vitamin $C$ (group $\mathrm{D}$ and $\mathrm{E})$ the LDH activity was significantly higher $(P \leqslant 0.05)$. This indicates that dietary high vitamin $C$ can reduce LDH activity inhibition by deltamethrin. The inhibition in the LDH activity due to deltamethrin exposure could either be due to changes in the conformation of active site [42], formation of enzyme-inhibitor complex leading to impairment of carbohydrate metabolism $[43,44]$ or reduction in de novo synthesis of proteins (enzymes).

Acetylcholine esterase (AChE) is one of the most widely used enzymes as a biomarker for environmental pollution. The highly decreased brain AChE activity was shown by group B; this might be due to the inhibitory effect of deltamethrin. Our results are in agreement with those obtained in Oreochromis niloticus, where exposure to insecticide diazinon showed reduced brain AChE activity [45]. However, vitamin C supplemented diet fed groups showed partial decrease in AChE activity. This might be due to the protective and anti-stress function of vitamin C. The significantly increased $(P \leqslant 0.05)$ ALT activity in control group (Group B) is might be due to dysfunction of liver. Shakoori et al. [28] suggested, inhibition of AST shows that oxaloacetate and glutamate are not available to Kreb's cycle through this route of transamination, but through ALT, which accounts for its increased activity. The inhibition of AST activity and over activity of ALT, however, were ameliorated in the group fed with high vitamin $C$ supplemented diet, suggesting their anti-stress ability.

The gill ATPase activity had been used as a sensitive biomarker for assessment of pollutant-induced damage to the osmoregulatory and acid-based regulatory system in the gills [46]. The deltamethrin exposure to Ancistrus multispinis inhibits the activity of the gills $\mathrm{Na}^{+}, \mathrm{K}^{+}$-ATPase [7]. The paper mill effluents containing various toxic constituents inhibit the gill ATPase activity in $C$. punctatus [47]. Similarly, inhibitions of the gill ATPase activity upon exposure to pesticides are well documented for other fishes $[48,49]$. These results are consistent with the findings of our present investigation, where we observed deltamethrin inhibit the gill ATPase activity (total ATPase activity, $\mathrm{Na}^{+} \mathrm{K}^{+}$-ATPase activity and $\mathrm{Mg}^{2+}$-ATPase activity) of fish fed with normal diet (group B). The reason for the inhibition of these enzymes could be due to lipophilic nature of deltamethrin. In some studies, it has been reported that the potent effect of TBTO on gill $\mathrm{Na}^{+}, \mathrm{K}^{+}$-ATPase might be explained by the fact that $\mathrm{Na}^{+}, \mathrm{K}^{+}$-ATPase is a lipoprotein and requires phospholipids for optimal activity [50,51]. It is therefore possible that deltamethrin or its lipophilic metabolites may bind to the lipid moiety in vivo which may result in altering the allosteric characteristic of the enzymes thus leading to the inhibition of its activity. The inhibition, however, was ameliorated in the group fed with high vitamin $C$ supplemented diet, suggesting their anti-stress ability. 
The present study concludes exposure of $C$. catla to sub lethal concentration of technical grade deltamethrin caused alteration in hematological and biochemical parameters. These alterations were reversed to a great extent with supplement of higher dose of vitamin $C$ in their diet. Taking this into account, cultured fishes can be protected against any possible pesticide stress using natural antioxidants such as vitamin $\mathrm{C}$ by incorporating it at higher level than it is normally required in the fish feed.

\section{Acknowledgments}

The authors are grateful to the Director, Central Institute of Fisheries Education, Mumbai, for providing facilities for carrying out the work. The first author is grateful to Indian Council of Agricultural Research, Delhi, for awarding junior research fellowship.

\section{References}

[1] K.M. Erstfeld, Environmental fate of synthetic pyrethroids during spray drift and field runoff treatments in aquatic microcosms, Chemosphere 39 (1999) 1737-1969.

[2] M. Kale, N. Rathore, S. John, D. Bhatnagar, Lipid peroxidation damage on pyrethroid exposure and alterations in antioxidant status in rat erythrocyte: a possible involvement of reactive oxygen species, Toxicol. Lett. 105 (1999) 197205.

[3] H. Fotoui, E. Garou, F. Makni-ayadi, N. Zeghal, Oxidative stress induced by Lambda-cyhalothrin (LTC) in rat erythrocytes and brain attenuation by vitamin C, Environ. Toxicol. Pharmacol. 26 (2008) 225-231.

[4] IARC, IARC Monographs on the evaluation of the carcinogenic risk of chemicals to humans. Occupational exposures in insecticide application, and some pesticides, vol. 53, International Agency for Research on Cancer, Lyon, 1991, pp. 1-612.

[5] C.T. Pimpa o, A.R. Zampronio, H.C.S. de Assis, Exposure of Ancistrus multispinis (Regan, 1912, Pisces, Teleostei) to deltamethrin: Effects on cellular immunity, Fish Shellfish Immunol. 25 (2008) 528-532.

[6] M.Ş. Ural, N. Sağlam, A study on the acute toxicity of pyrethroid deltamethrin on the fry rainbow trout (Oncorhynchus mykiss Walbaum, 1792), Pestic. Biochem. Physiol. 83 (2005) 124-131.

[7] H.C.S. de Assis, L. Nicareta, L.M. Salvo, C. Klemz, J.H. Truppel, R. Calegari, Biochemical biomarkers of exposure to Deltamethrin in freshwater fish Ancistrus multispinis, Braz. Arch. Biol. Technol. 52 (2009) 1401-1407.

[8] M. Crane, L. Maltby, The lethal and sublethal responses of Gammarus pulex to stress: sensitivity and sources of variation in an in situ bioassay, Environ. Toxicol. Chem. 10 (1991) 1331-1339.

[9] P. Miren, M.J. Cajaraville, J.B. Bebianno, P. Cinta, S. Carmen, V. Aldo, The use of biomarkers to assess the impact of pollution in coastal environments of the Iberian peninsula: a practical approach, Sci. Total Environ. 247 (2000) 295-311.

[10] J. Rendón-von Osten, A. Ortíz-Arana, L. Guilhermino, A.M.V.M. Soares, In vivo evaluation of three biomarkers in the mosquitofish (Gambusia yucatana) exposed to pesticides, Chemosphere 58 (2005) 627-636.

[11] M.A. Thrall, Veterinary Hematology and Clinical Chemistry, Williams \& Wilkins, Philadelphia, 2004. pp. 277-289.

[12] I.B. Chatterjee, A.K. Majunmder, B.K. Nandi, N. Subramanian, Synthesis and major functions of vitamin C in animals, Ann. NY Acad. Sci. 258 (1975) 24-48.

[13] J. Blom, K. Dabrowski, Vitamin C requirements of the angelfish, Pterophylum scalare, J. World Aquacult. Soc. 31 (2000) 115-118.

[14] F. Garcia, F. Pilarski, E.M. Onaka, F.R. Moraes, M.L. Martins, Hematology of Piaractus mesopotamicus fed diets supplemented with vitamins C and E, challenged by Aeromonas hydrophila, Aquaculture 271 (2007) 39-46.

[15] M. Datta, A. Kaviraj, Ascorbic acid supplementation of diet for reduction of deltamethrin induced stress in freshwater catfish Clarias gariepinus, Chemosphere 53 (2003) 883-888.

[16] J. Ortuño, M.A. Esteban, J. Meseguer, The effect of dietary intake of vitamins C and $\mathrm{E}$ on the stress response of gilthead seabream, Sparus aurata, Fish Shellfish Immunol. 14 (2003) 145-156.

[17] X. Zhou, C. Niu, R. Sun, The effect of vitamin C on stress withstanding capability in the juvenile soft-shelled turtle, Pelodicus sinensis, Aquacult. Nutr. 11 (2005) 169-174.

[18] D.L. Reish, P.A. Oshida, Manual of methods in aquatic environment research, Part 10, Short-term static bioassay, FAO Fisheries Technical Paper, 247. FAO, Rome, 1987 pp. $1-62$.

[19] W. Schaperclaus, H. Kulow, K. Schreckenbach, Hematological and serological technique, in: V.S. Kothekar (Eds.), Fish Disease, vol. 1, 2nd ed., Gulab Primlani, Oxonian Press, New Delhi, India, 1991, pp. 71-108.

[20] L. Wroblewski, J.S. Ladue, LDH activity in blood, Proc. Soc. Exp. Biol. Med. 90 (1955) 210-213.

[21] I.D.P. Wotton, Microanalysis, in: Medical Biochemistry, 4th ed. J. \& A. Churchill, London, 1964, pp. 101-107.

[22] L. Hestrin, The reaction of Acetyl choline esters and other carboxylic acid derivatives with hydroxylamine and its analytical application, J. Biol. Chem. 180 (1949) 249-261.
[23] K.B. Augustinsson, Assay methods for cholinesterases, Methods Biochem. Anal. 5 (1957) 1-63.

[24] R.L. Post, A.K. Sen, Sodium and potassium-stimulated ATPase, in: S.P. Colowick, N.O. Kaplan (Eds.), Methods in Enzymology, vol. 10, Academic Press, New York, 1967, pp. 762-768.

[25] C.H. Fiske, Y. Subbarow, The colorimetric determination of phosphorus, J. Biol. Chem. 66 (1925) 375-400.

[26] F. Jenkins, J. Smith, B. Rajanna, U. Shameem, K. Umadevi, V. Sandhya, R Madhavi, Effect of sub lethal concentration of endosulfan on hematological and serum biochemical parameters in the carp, Cyprinus carpio, Bull. Environ. Contam. Toxicol. 70 (2003) 993-997.

[27] Z. Svobodova, V. Luskova, J. Drastichova, M. Svoboda, V. Zlabek, Effect of deltamethrin on haematological indices of commom carp (Cyprinus carpio L.), Acta. Vet. Brno. 72 (2003) 79-85.

[28] A.R. Shakoori, A.L. Mughal, M.J. Iqbal, Effects of sublethal doses of Fenvalerate (a synthetic pyrethroid) administered continuously for four weeks on the blood, liver and muscles of a freshwater fish, Ctenopharyngodon idella, Bull. Environ. Contam. Toxicol. 57 (1996) 487-494.

[29] A. Sopinska, L. Guz, Influence of permethrin on phagocytic activity of carp, Med. Wet. 54 (1998) 126-128.

[30] J. Ortuńo, M.A. Esteban, J. Meseguer, Effect of high dietary intake of vitamin C on non-specific immune response of gilt head sea bream (Sparus aurata L.), Fish Shellfish Immunol 9 (1999) 429-443.

[31] I. Thompson, A. White, T.C. Fletcher, D.F. Houlihan, C.J. Secombes, The effect of stress on the immune response of Atlantic salmon (Salmo salar L.) fed diets containing different amount of vitamin C, Aquaculture 114 (1993) 1-18.

[32] N.K. Agrawal, C.J. Juneja, C.L. Mahajan, Protective role of ascorbic acid in fishes exposed to organochlorine pollution, Toxicolology 11 (1978) 369-375.

[33] J. Velisek, Z. Svobodova, J. Machova, Effects of bifenthrin on some haematological, biochemical and histopathological parameters of common carp (Cyprinus carpio L.), Fish Physiol. Biochem. 35 (2009) 583-590.

[34] L.H. Jee, F. Masroor, J.C. Kang, Response of cypermethrin-induced stress in haematological parameters of Korean rock fish, Sebastes schlegeli (Hilgendorf.), Aquac. Res. 36 (2005) 898-905.

[35] S.Y. Hussein, M.A. El-Nasser, S.M. Ahmed, Comparative studies on the effects of herbicide Atrazine on freshwater fish Oreochromis niloticus and Chrysichthyes auratus at Assiut, Egypt. Bull. Environ. Contam. Toxicol. 57 (1996) 503-510.

[36] D.P. Anderson, A.K. Siwicki, Basic haematology and serology for fish health programs, In: M. Shariff, J.R. Arthur, R.P. Subasinghe (Eds.), Diseases in Asian Aquaculture II, Fish Health Section, Asian Fisheries Society, Manila, Philippines, 1995, pp. 185-202.

[37] H.M. Dutta, A composite approach for evaluation of the effects of pesticides on fish, In: J.S.D. Munshi, H.M. Dutta (Eds.) Fish Morphology: Horizon of New Research, Lebanon, New Hampshire Science Publishers Inc. and Oxford IBH, India, 1996, pp. 249-269.

[38] H.M. Dutta, S. Adhikari, N.K. Singh, P.K. Roy, J.S. Munshi, Histopathological changes induced by malathion in the liver of a freshwater catfish Heteropneustes fossilis (Bloch), Bull. Environ. Contam. Toxicol. 51 (1993) 895900.

[39] A.K. Nayak, B.K. Das, M.P.S. Kohli, S.C. Mukherjee, The immunosuppressive effect of $\alpha$-permethrin on Indian major carp, rohu (Labeo rohita Ham.), Fish Shellfish Immunol 16 (2004) 41-50.

[40] P. Sebert, B. Simon, L. Barthelemy, Hydrostatic pressure induces a state resembling histotoxic hypoxia in Anguilla Anguilla, Comp. Biochem. Physiol. 105B (1993) 255-258.

[41] V.M.F. Almeida-Val, I.P. Farias, M.N.P. Silva, W.P. Duncan, A.L. Val, Biochemical adjustments to hypoxia by Amazon cichlids, Braz. J. Med. Biol. Res. 28 (1995) 1257-1263.

[42] S. Valarmathi, J. Azariah, Impact of chlorine on crab, Sesarma quadratum, J. Natcon 14 (2002) 21-26.

[43] Z.L. Copper, G.N. Somero, Temperature differences between the M41 lactate dehydrogenase of stenothermal and eurythermal sciaenid fishes, J. Exp. Zool. 254 (1990) 127-133.

[44] B. Sharma, K. Gopal, Change in lactic acid contents and activity of lactate dehydrogenase in C. batrachus exposed to carbaryl, Toxicol. Environ. Chem. 47 (1995) 89-95.

[45] N. Üner, E.O. Oruç, Y. Sevgiler, N. Sahin, H. Durmaz, D. Usta, Effects of diazinon on acetyl cholinesterase activity and lipid peroxidation in the brain of Oreochromis niloticus, Environ. Toxicol. Pharmacol 21 (2006) 241-245.

[46] R.M. Stagg, J. Rusin, F. Brown, $\mathrm{Na}^{+}, \mathrm{K}^{+}$-ATPase activity in the gills of the flounder (Platichthys flesus) in a relation to mercury contamination in the Firth of Forth, Mar. Environ. Res. 33 (1992) 255-266.

[47] S. Parveza, I. Sayeedb, S. Raisuddinc, Decreased gill ATPase activities in the freshwater fish Channa punctata (Bloch) exposed to a diluted paper mill effluent, Ecotoxicol. Environ. Safety 65 (2006) 62-66.

[48] M.G. Lionetto, M.E. Giordano, S. Vilella, T. Schettino, Inhibition of eel enzymatic activities by cadmium, Aquat. Toxicol. 48 (2000) 561-571.

[49] C.P. Waring, A. Moore, The effect of atrazine on Atlantic salmon (Salmo salar) smolts in fresh water and after sea water transfer, Aquat. Toxicol. 66 (2004) 93-104.

[50] R.B. Laughlin, H.E. Guard, W.M. Coleman, Tributyltin in sea water: speciation and octanol-water partition coefficient, Environ. Sci. Technol. 20 (1986) 201204.

[51] R.D. Morero, B. Bloj, R.N. Farias, R.E. Trucco, The allosteric transitions from membrane bound enzymes: Behaviour of erythrocyte acetyl cholinesterase from fat deficient rats, Biochem. Biophys. Acta 258 (1972) 157-165. 